\title{
Phytoglycoproteins and Human Health: Current Knowledge and Future Applications
}

\author{
Innocent U. Okagu ${ }^{1}\left(\mathbb{D}\right.$, Ikenna C. Ohanenye $^{2}\left(\mathbb{D}\right.$, Timothy P. C. Ezeorba ${ }^{1}(\mathbb{D})$ and Chibuike C. Udenigwe ${ }^{2,3, *(\mathbb{D})}$ \\ 1 Department of Biochemistry, Faculty of Biological Sciences, University of Nigeria, Nsukka 410001, Nigeria; \\ innocent.okagu@unn.edu.ng (I.U.O.); timothy.ezeorba@unn.edu.ng (T.P.C.E.) \\ 2 School of Nutrition Sciences, Faculty of Health Sciences, University of Ottawa, Ottawa, ON K1H 8M5, Canada; \\ iohaneny@uottawa.ca \\ 3 Department of Chemistry and Biomolecular Sciences, Faculty of Science, University of Ottawa, Ottawa, \\ ON K1N 6N5, Canada \\ * Correspondence: cudenigw@uottawa.ca
}

Citation: Okagu, I.U.; Ohanenye, I.C.; Ezeorba, T.P.C.; Udenigwe, C.C. Phytoglycoproteins and Human Health: Current Knowledge and Future Applications. Appl. Sci. 2021, 11, 5532. https://doi.org/10.3390/ app11125532

Academic Editor: Andrea Salvo

Received: 17 May 2021

Accepted: 7 June 2021

Published: 15 June 2021

Publisher's Note: MDPI stays neutral with regard to jurisdictional claims in published maps and institutional affiliations.

Copyright: (c) 2021 by the authors. Licensee MDPI, Basel, Switzerland. This article is an open access article distributed under the terms and conditions of the Creative Commons Attribution (CC BY) license (https:/ / creativecommons.org/licenses/by/ $4.0 /)$.

\begin{abstract}
Over the years, humans have relied on plants as sources of nutrients and bioactive compounds that promote health and wellness. Interestingly, drug discovery has benefitted immensely from the use of bioactive phytochemicals derived from food and medicinal plants. Phytoglycoproteins (PGPs) are plant-derived proteins with sugar moieties covalently linked to amino acid side chains, formed by glycosylation during posttranslational modification of polypeptides. Several studies in the last two decades, including cell culture and animal studies, have documented a variety of health-beneficial effects of PGPs, including hypolipidemic, wound healing, antioxidant, anti-inflammatory, immunomodulatory, and anticancer properties. Despite the prospects, there is a dearth of information on the pharmacokinetics and toxicity of PGPs, including possible induction of immune reactions, and the potential effects of stereospecific variation in PGPs isomers on their physiological functions. Further exploration of the multifunctional glycoproteins will position them as strong candidates for the development of nutraceuticals and functional foods.
\end{abstract}

Keywords: phytoglycoproteins; glycoproteins; bioactive proteins; health benefits; nutraceuticals; functional foods

\section{Introduction}

Interest in plant-derived medicinal products has increased in the past decades due to perceived safety and heightened scientific efforts to validate their health benefits. The plant molecules generally stimulate the body's defense machinery against aberrations and promote the restoration of normal physiological processes in disease state [1]. These effects are achieved by binding of the plant molecules directly to their cellular targets to elicit physiological responses, or by altering the activities of gut microbiota to generate chemicals that promote health and wellness [2]. Among the many molecules produced in plants, glycoproteins have been demonstrated to poses many health promoting properties, such as inhibition of oxidative stress-mediated cellular damages, inflammation, cell proliferation and cytotoxicity, antimicrobial, immunomodulatory, cytoprotective, and wound healing properties [3-8]. Phytoglycoproteins (PGPs) have been isolated from several plant species, including Dioscorea batatas Decne, Gardenia jasminoides Ellis, Trachyspermum ammi L., Solanum nigrum Linne, Rhus verniciflua STOKES, Zanthoxylum piperitum DC fruit, and Cudrania tricuspidata Bureau [9-11]. This review discusses current knowledge on the nature and occurrence of PGPs, their biological activities including cellular and molecular mechanisms, bioavailability and toxicity, as well as future research directions for their application in developing nutraceuticals and functional foods. 


\section{Structural Features and Occurrence of Phytoglycoproteins}

Phytoglycoproteins refers to glycoproteins of plant origin. Glycoproteins are a diverse class of macromolecules that contain glycan moieties covalently linked to the polypeptide side chains. They differ slightly from proteoglycans, which have a major polysaccharide backbone linked to a few amino acid residues. Both classes are composed of protein and carbohydrate moieties and, hence, express slightly similar biological properties [12]. The process of glycosylation, which is a posttranslational modification, adds glycan residues to several proteins to achieve their functions in biological systems [13]. Several types of glycosylation, such as N-, O-, P-, C- and S-glycosylation, can be found in living systems. However, PGPs are majorly N-glycosylated or O-glycosylated with one or more heteroglycans possessing two to fifteen sugar residues [14].

Glycoproteins have diverse sublocations in plants ranging from the cell wall of vascular bundles, sclerenchyma cells, pollen and pollen tubes, plasma membrane, endoplasmic reticulum, Golgi bodies and intravesicular bodies. Plant-derived glycoprotein are biosynthesized and modified within plant endoplasmic reticulum and Golgi bodies and then packaged as secretory vesicles for transport to different parts of the plants [15]. The syntheses PGPs begin from the formation and translocation of activated nucleotide sugars from the cytosol to the endoplasmic reticulum and Golgi bodies. The activated sugars serve as precursors for building the glycan oligosaccharides through reactions catalyzed by sugar-specific glycosyltransferases [16].

Plant cell walls are made up of 10-15\% glycoproteins and have been reported to be the largest depot of both $\mathrm{N}$ - and O-glycosylated proteins [15]. N-glycoproteins in plants are more conserved in higher plants and Eukaryotic organisms and have more pharmaceutical relevance than O-glycoproteins [17]. Several studies have shown that N-glycoproteins play a vital role in conserving the integrity of many protein folding events. In contrast, $\mathrm{O}$ glycoproteins have mainly structural relevance, some catalytic and translocation activities in plants [18].

$\mathrm{N}$-glycosylation common in plants involves the en bloc transfer of mature glycan (comprising mainly 2 GlcNAc, 9 Mannose and 3 glucose- $-\mathrm{Glc}_{3} \mathrm{Man}_{9} \mathrm{GlcNAc}_{2}$ ) on a lipid carrier to selected asparagine residues (Asn) in the nascent polypeptide chain. The glycan used for N-glycosylation is formed in the endoplasmic reticulum (ER) in two phases (Phase I and Phase II). The steps in Phase I occurs on the cytoplasmic side of the ER and involves the attachment of 2 UDP-activated GlcNAc to Dolichol, and then 5 GDP-activated mannose to the GlcNAc, yielding a product Dolichol-GlcNAc $-\mathrm{Man}_{5}$. Dolichol comprises of repeating chains of isoprene and is the lipid carrier of the mature glycan in the ER [17]. The Phase II for the formation of mature glycan N-glycosylation takes place in the luminal side of the endoplasmic reticulum. The product of Phase I is translocated across the membrane to the ER lumen through an unknown mechanism by an enzyme, flippase. In Phase II, 4 mannose (activated in the form of dolicol phosphate-activated mannose) and 3 glucose (activated in the form of dolicol phosphate-activated glucose) are added respectively to the growing glycan chain, yielding the matured glucan (Dolichol-GlcNAc $2-\mathrm{Man}_{9}-\mathrm{Gl}_{3}$ ) [17].

Moreover, in the lumen of the ER, the mature glycan is translocated to an asparagine residue in the nascent polypeptide chain by specific oligosaccharyltransferases (OTase). Studies have revealed that not all asparagine residues in polypeptide sequences are suitable N-glycosylation sites. For an asparagine to be glycosylated, it must first appear in a consensus sequence referred to as sequon. A plant sequon (represented as 'Asn-X-Ser/Thr') generally contains an asparagine residue (Asn) adjacent to two other residues. The second residue after Asn could be serine (Ser) or threonine (Thr), whereas the mid residue (represented as " $X$ " in the sequon) can be any amino acid except proline [19]. The asparagine sequence must be on the surface of the three-dimensional folded nascent polypeptide rather than embedded in the structure. Finally, the asparagine should be in the lumen of the ER [18]. After the attachment of the matured glycan to the asparagine of the polypeptide, the final glycoprotein product is further processed, first in the ER and then in the Golgi 
apparatus (Figure 1) by the removal of one or two glucose moieties based on the folding pattern of the protein [19].

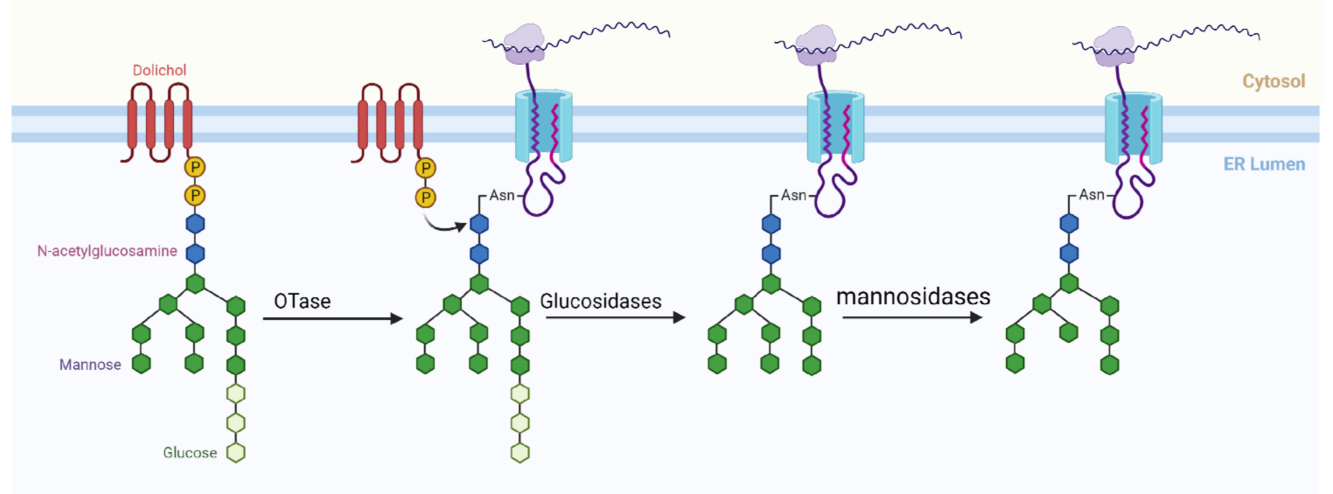

Figure 1. The process of N-glycosylation of proteins in plant endoplasmic reticulum.

Like N-glycosylation that attach glycan molecules to Asn, O-glycosylation attaches the glycan moieties to mainly hydroxylated form of proline (hydroxylproline; $\mathrm{HyP}$ ) and Ser residues. O-glycoproteins have two major subclasses named arabinogalactan-proteins (AGPs) and extensins. Extensins have regular structures involving glycosylation of a pentapeptide residue, Ser-HyP-HyP-HyP-HyP. Hydroxyproline (HyP) is produced as a post-translation modification in the lumen of the ER by hydroxylation of $\mathrm{Cg}$ of proline by propyl hydroxylase [20]. Peptide sequences with 3 or $5 \mathrm{HyP}$ are common sites for O-glycosylation [21]. In the Ser residue, monogalactosylation takes place whereas in the HyP residue oligoarabinosylation occurs to produce structurally relevant extensins. In contrast, AGPs are the most bulky and complex structured glycoproteins and have a disproportionate arrangement of their oligopeptides attached to several uninformed cross-linkages of polysaccharides. AGPs have major structural relevance in cells [21].

Glycoproteins have been studied extensively in the past using several methodologies, which mainly involve hydrolysis of the glycoprotein into its oligoglycan and polypeptide, and maybe further into its monosaccharides [22]. In most studies, crude isolation of the glycoproteins is done using affinity chromatography $[7,23,24]$ or ammonium sulphate precipitation [25-27] and dialysis. The existence of proteins and carbohydrates in the extract is essentially confirmed by checking absorbances at 280 and $490 \mathrm{~nm}$ for protein-rich and carbohydrate-rich fractions, respectively. Thereafter, the existence of a band with Schiff's reagent on sodium dodecyl sulfate-polyacrylamide gel electrophoresis (SDS-PAGE) confirms the existence of glycoproteins. More recent approaches have applied advanced chromatographic techniques to analyze intact glycoproteins without hydrolysis. The techniques separate glycoprotein mixtures on the basis of their molecular weights, which are further used for identification and classification [28]. This approach presents ambiguity particularly when identifying glycoproteins with identical molecular weight and different atomic arrangements and stereo-conformations. Since several biologically active compounds are stereo-specific, varying results of the biological activities may be achieved if the stereo-specificity of isolated phytoglycoproteins is taken into consideration. A recent review by Lojkova et al. [29] described the stereospecificity in both simple and complex carbohydrates and their diverse roles. Despite the paucity of studies on the relevance of stereospecificity on bulky macromolecules, the chirality of monosaccharides that make up the matured glycans may influence the properties of the nascent glycoprotein, and hence its biological activities. Therefore, further work is needed in developing comprehensive workflow targeted towards eliminating ambiguity in identifying plant-specific glycopro- 
teins. Advanced techniques such as NMR, mass spectroscopy and X-ray crystallography could be adopted for accurate structural elucidation of specific glycoprotein isomers. This will provide more information on the structure-function relationships of glycoproteins, and the nature of interaction between the intact glycoproteins or their metabolites with molecular targets in the body.

\section{Bioactive Properties of Phytoglycoproteins}

Phytoglycoproteins have been demonstrated to display many biological activities, based on in vitro, cell culture and animal studies. Based on current scientific knowledge, the biological activities of PGPs, as discussed below, include anticancer, anti-inflammatory, immunomodulatory, antioxidant, chemoprotective, wound healing properties and modulation of glucose and lipid metabolism. The multifunctional effects make PGPs attractive as suitable bioactive candidates for functional food, nutraceutical and biomedical applications.

\subsection{Anticancer and Chemopreventive Properties}

Cancer is a growing public health challenge worldwide. The ability of synthetic or natural molecules to reduce or reverse the growth, development and spread of cancer cells in vitro or in vivo is known as anticancer activity whereas chemoprevention represents the inhibition of carcinogenesis. Anticancer agents can act by suppressing tumor initiation and progression and proliferation of cancer cells via the induction of apoptosis and cell cycle arrest. PGPs have been shown to possess anticancer and chemopreventive properties. For instance, in both HepG2 cells in vitro and mouse bearing hepatocellular carcinoma (H22) tumor cells, CO glycoproteins derived from seeds of Camellia oleifera was reported to exhibit significant antiproliferative and anticancer activities by inducing cell cycle arrest and apoptosis [30]. Additionally, a sweet potato-derived glycoprotein (SPG-56) was shown to suppress human breast cancer (MCF-7) cell line up to $80 \%$ in an in vitro assay. Similarly, SPG-56 at 60, 120 and $240 \mathrm{mg} / \mathrm{kg}$ body weight dose-dependently induced apoptosis and inhibited metastasis in MCF-7 and mouse breast cancer (4T1-Luc) cell line-grafted female BALB/c nude mice [31]. Furthermore, a glycoprotein isolated from sweet potato (SPG-8700) was reported to significantly induce apoptosis in colorectal cancer (HCT-116) cells, indicating anti-colorectal cancer activity [32]. Based on these studies, it can be inferred that the glycoproteins sourced from Camellia oleifera seeds and sweet potatoes can be further investigated as dietary agents against colorectal, breast and liver cancers. Another study conducted in 1,2-dimethylhydrazine-treated mice showed that phytoglycoproteins from stem extract of Ulmus davidiana Nakai (UDP) activated the proliferating cell nuclear antigen and inhibited aberrant crypt foci in the colon, and also decreased the activities of nuclear factor-kappa B (NF-kB) and activator protein-1 (AP-1) and downstream inflammatory cytokines and enzymes [33]. Similar effects were reported for phytoglycoproteins extracted from Solanum nigrum Linne (Black Nightshade or Makoi) in addition to stimulation of apoptosis by the release of cytochrome c into the cytosol, activation of caspases 8 and 3 , and cleavage of poly(ADP-ribose) polymerase in cervical cancer (HeLa) cells [34]. Other cellular mechanisms have been reported for PGPs. Matrix metalloproteinase-9 (MMP-9) is an enzyme involved in angiogenesis and thus is strongly linked to tumor neovascularization and proliferation of cancer cells [35]. Thus, inhibition of the activities of MMP-9 would reduce metastasis and proliferation of cancer cells, which are desired outcomes in cancer treatment and management. Phytoglycoproteins extracted from Styrax japonica Siebold and Zuccarini (SJSZ) was reported to suppressed MMP-9 activities, which caused the suppression of metastasis in hepatocellular carcinoma following intraperitoneal administration to diethylnitrosamine-treated mice [36].

Furthermore, DBD phytoglycoproteins from Dioscorea batatas Decne at $200 \mu \mathrm{g} / \mathrm{mL}$ were shown enhance the activity of AP-1, a transcription factor that regulates cell proliferation and induces apoptosis in BPA-induced cellular proliferation of Chang liver cells. The phytoglycoprotein also increased the activities of catalase (CAT) and glutathione per- 
oxidase (GPx) in the cells [10]. This suggests that the D. batatas-derived glycoproteins exhibited anticancer property by halting cellular proliferation, and oxidative stress.

Although MMP-9 inhibition reduces cancer cell growth, cancer cell proliferation involves other players and pathways such as the phosphorylated ERK, NF-KB and MAPK. PGPs are known to elicit multifaceted inhibition of these other pathways involved in cancer cell growth. For instance, SJSZ phytoglycoproteins when administered to murine embryonic liver (BNL CL.2) cells treated with a chemical mutagen inhibited aberrant cell proliferation at the initiation stage by reducing the activities of phosphorylated ERK, cyclin D1/CDK4, PCNA, NF-KB (p50 and p65), p38 MAPK, and intracellular ROS production $[37,38]$. Taken together, available studies have significantly advanced knowledge on the chemopreventative properties of PGPs. However, information on the anticancer effects of phytoglycoproteins is limited compared to phytochemicals such as terpenoids and flavonoids. Furthermore, there is a paucity in knowledge on the identification of specific PGPs that are effective in chemoprevention. Therefore, future studies on the chemopreventative and anticancer properties of PGPs should focus on detailed structural characterization of PGPs and elucidation of the bioactivity mechanisms in different cancer cell types to enhance their incorporation in cancer prevention and treatment. In addition, due to the complex, bidirectional role of gut microbiota in cancer formation and treatment, there is a need to examine the potential role of gut microbiota in the anticancer activities of PGPs.

\subsection{Anti-Inflammatory and Immunomodulatory Properties}

PGPs have demonstrated anti-inflammatory effects in endotoxin-induced inflammation. Lipopolysaccharides (LPS) stimulate inflammation via activation of NF- $\mathrm{KB}$ and other inflammation signaling pathways, leading to upregulation of gene expression of inducible nitric oxide synthase (iNOS), cyclooxygenase (COX)-2 and pro-inflammatory cytokines such as interleukins and tumor necrotic factor (TNF)- $\alpha$. A 36-kDa phytoglycoprotein from Rhus verniciflua STOKES was reported to suppress LPS-induced inflammation in RAW 264.7 macrophages by activating protein kinase $\mathrm{C}(\mathrm{PKC})$, and suppressing intracellular ROS production and expression of NF- $\mathrm{kB}$ and AP-1, leading to downregulation of COX-2 and iNOS gene expression [39]. Similar effects of PGPs have been reported in other inflammation models. For example, in inflammation induced by Bisphenol A, a xenoestrogen known to induce uncontrolled cell proliferation, inflammation and oxidative stress, a 30-kDa phytoglycoprotein (carbohydrate-protein ratio of 5:1) from D. batatas Decne at $200 \mu \mathrm{g} / \mathrm{mL}$ was shown to abrogate the proliferation of cultured Chang liver cells by reducing intracellular ROS and nitric oxide production through inhibition of MAPK activation, an indication of anti-inflammatory property [10].

Furthermore, the $D$. batatas phytoglycoprotein was later reported to suppress allergic processes in cultured lymphocytes sensitized with ovalbumin by downregulating the expression of IL-4 and IL-10 while upregulating that of IFN- $\gamma$ via blocking of GATA-3, STAT-6, p44/42 MAPK and p38 MAPK signaling pathways [4]. In another study, a 24-kDa glycoprotein from Z. piperitum DC fruit inhibited the release of IL-4, histamine and immunoglobin E in experimentally-induced allergy in mice at $10 \mathrm{mg} / \mathrm{kg}$ body weight. At lower doses, the glycoprotein inhibited the degranulation of human mast (HMC-1) cells, reduced intracellular calcium ion, and downregulated the activation of MAPK, NF- $\mathrm{KB}$ and COX-2 signaling pathways, all of which contributed to the prevention of allergic inflammation [40]. Moreover, a 75-kDa phytoglycoprotein from Cudrania tricuspidata at $100 \mu \mathrm{g} / \mathrm{mL}$ was shown to suppress Bisphenol A-induced inflammation by inhibiting the gene expression of TNF- $\alpha$ and IL-6 [41] and IL-4, IFN- $\gamma$, IL-1 $\beta$ and COX-2 [42] in cultured HMC-1 cells via blocking of NF- $\mathrm{KB}$ and PKC/p38 kinase signaling pathways. Several other PGPs have been shown to possess anti-inflammatory properties following the above mechanisms, despite being sourced from different plant species and having varied molecular weights. This evidence suggests possible similarity in the PGPs structural motifs responsible for the bioactivity. In addition to these cellular mechanisms, PGPs from Z. piperitum was also shown to in- 
hibit c-Jun N-terminal kinase (JNK) and MMP-9 gene expression in LPS-challenged RAW 264.7 macrophages [43], suggesting multiple mechanisms of the phytoglycoprotein in abrogating inflammation. Through the mechanisms, a 75-kDa phytoglycoprotein extracted from C. tricuspidata Bureau was reported to reduce pathological process of inflammatory bowel disease by stimulating signaling processes related to proliferation in colon epithelial (HT-29) cells [8].

The immunomodulatory property of PGPs was demonstrated in a study where a 38-kDa glycoprotein isolated from Styrax japonica (SJP) normalized the proliferation of cells of the immune system, phagocytic activities of macrophages, antioxidant status and gene expression profiles of IL-2, IL-12, and IFN- $\gamma$ in cyclophosphamide-immunosuppressed mice [44]. Similarly, rice bran-derived glycoproteins were reported to stimulate immune response in cultured cells and animals. In RAW 264.7 macrophages, the rice bran PGPs stimulated the expression of iNOS and concomitant production of NO, and TNF- $\alpha$, IL-1 $\beta$, IL-6, and IL-10 [45]. In both normal and immunocompromised (cyclophosphamide-induced) mice, the rice bran PGPs also enhanced $\mathrm{T}$ and $\mathrm{B}$ cell-producing capacities of splenic lymphocytes, and normalized splenic structure and functionality, and leukocyte count in immunocompromised mice [46]. In addition, a 30.7- $\mathrm{kDa}$ glycoprotein derived from Trachyspermum ammi $(1 \mu \mathrm{g} / \mathrm{mL})$ was recently shown to enhance the proliferation of B-cell rich murine splenocytes, and improve nitric oxide, IL-12, TNF- $\alpha$ and IFN- $\gamma$-producing and phagocytotic activities of macrophages [6]. Despite the promising results, there is currently limited in vivo evidence and lack of human studies to demonstrate the physiological relevance of the bioactivities.

\subsection{Antioxidant and Chemoprotective Properties}

Some PGPs possess direct or indirect antioxidant effects in cells. Considering that the effects of hepatotoxins are initiated through oxidative and inflammatory damages, many agents with antioxidant and anti-inflammatory properties are believed to exert hepatoprotective effects. In a chemically-induced, cellular injury generated by $12-\mathrm{O}-$ tetradecanoylphorbol 13-acetate (TPA), a toxicant that initiates tumor formation by enhancing oxidative stress and activating PKC and iNOS signaling pathways, the chemopreventative potential of UDP glycoprotein with radical scavenging properties was demonstrated in NIH/3T3 cells. Lee et al. [47] reported that PGPs at $100 \mu \mathrm{g} / \mathrm{mL}$ blocked the activation of PKC and NF-kB, nitric oxide release and apoptosis in the oxidant-challenged $\mathrm{NIH} / 3 \mathrm{~T} 3$ cells. Furthermore, PGPs exhibited hepatoprotective effects by protecting the hepatic membrane against oxidative damage and leakage of intrahepatic enzymes into circulation, reducing ROS formation and gene expression of NF-kB and AP-1, and boosting the activities of antioxidant enzymes and nitric oxide production in models of acute liver injury [48,49]. Additionally, UDP glycoprotein suppressed was shown to increase nitric oxide level and activities of (superoxide dismutase (SOD)), CAT and GPx in Triton WR1339-treated mouse [50], signifying the robust antioxidant and cellular-protective potentials of UDP glycoproteins in many models of oxidative stress. Similarly, SNP glycoprotein was shown to protect MCF-7 cells from TPA-generated cytotoxicity by inhibiting DNA binding of AP-1 and NF-kB and preventing apoptosis [51].

Glucose/glucose oxidase (G/GO) system induces intracellular ROS production leading to cytotoxicity, and is hence used as a study model for investigating the cellular antioxidant property of compounds. After observation of ferric ion-chelating activities, Lee and co-workers [9] reported that Gardenia jasminoides (GPG) glycoprotein suppressed ROS production and cytotoxicity in BNL CL.2 cells subjected to G/GO oxidative challenge. The authors also showed that GPG glycoprotein at $80 \mathrm{mg} / \mathrm{kg}$ suppressed the formation of Thiobarbituric acid reactive substances (TBARS) and leakage of hepatic lactate dehydrogenase (LDH) into circulation whereas it improved nitric oxide production and hepatic antioxidant enzyme activities in carbon tetrachloride-challenged mice by suppressing hepatic cytochrome $c$, NF-kB and AP-1 gene expression. In another study, ZPFG glycoprotein was reported to possess excellent radical scavenging activities against superoxide 
anion and hydroxyl radicals, and suppressed oxidation-mediated cytotoxicity generated by hypoxanthine/xanthine oxidase and G/GO systems in Chang liver and BNL CL.2 (murine liver) cell lines [52]. The authors further demonstrated that ZPFG glycoprotein $(20 \mathrm{mg} / \mathrm{kg})$ protected mouse hepatocytes from carbon tetrachloride-induced acute hepatotoxicity by suppressing the leakage of hepatic enzymes (LDH and alanine aminotransferase (ALT)) into circulation, and reducing the formation of TBARS in serum, as well as boosting of hepatic antioxidant status (SOD, CAT and GPx activities). Based on previous knowledge that antioxidant mechanism is involved in hepatoprotection, PGPs were demonstrated that ZPFG glycoprotein (50 $\mu \mathrm{M}$ in cultured hepatocytes and $10 \mathrm{mg} / \mathrm{kg}$ in ICR mice) exhibited hepatoprotective effect by reducing circulating ALT and LDH, suppressing ROS production by downregulating gene expression profiles of heme oxygenase and metallothionein, and enhancing the activities of hepatic SOD, CAT and GPx in heavy metal-induced hepatotoxicity [5]. In addition, ZPFG glycoprotein inhibited the production of inflammatory mediators (prostaglandins, nitric oxide and pro-inflammatory cytokines) in hepatocytes through the downregulation of ERK, p38 MAPK, COX-2, iNOS, AP-1 and Nrf-2 gene expression [53]. These results suggest that ZPFG glycoprotein protects hepatocytes via the co-involvement of antioxidant and anti-inflammatory mechanisms.

In ICR mice challenged with $\mathrm{N}$-nitrosodiethylamine, a hepatotoxin that causes hepatic inflammation and hepatocarcinogenesis, treatment with SJP glycoprotein $(5$ or $10 \mathrm{mg} / \mathrm{kg})$ for 49 days dose-dependently prevented hepatic damage by lowering the activities of serum LDH and ALT, and reduced oxidative stress as evidenced by lower TBARS level and higher activities of antioxidant enzymes (SOD, CAT and GPx) [54]. In addition, SJP glycoprotein suppressed the expression of genes associated with hepatocarcinogenesis, such as heat shock proteins 27 and 70, PKC, ERK 1/2, NF-kB (p50 and p65) and TNF- $\alpha$, which imply that the PGPs possess hepatoprotective effects and could be further explored in functional food development for promoting liver health. Interestingly, the chemopreventive effects of glycoproteins have been reported in some animal studies, suggesting that their fragments or metabolites might be bioavailable and reach their targets to induce the relevant bioactivities. In addition, the consumption of the glycoproteins might have modulated the population and growth of gut microbiota to indirectly generate metabolites, which may elicit antioxidant and chemoprotective properties. Chemopreventive and anticancer therapies can be enhanced by modulating the microbiota in a manner that promote the beneficial organisms [55].

\subsection{Wound Healing Property}

Dioscorea batatas Decne is traditionally used in Asia to treat stomach disorders, and this inspired studies on the wound healing activity of its PGPs. For example, treatment of human intestinal epithelial (INT-407) cells with $100 \mu \mathrm{g} / \mathrm{mL}$ of DBP glycoproteins enhanced the cell mobility by improving the activities of PKC and p38-MAPK, leading to the activation of NF- $\mathrm{kB}$ signaling pathway and the downstream effects such as upregulation of expression of profilin-1 (PFN1), $\alpha$-actinin and F-actin [7]. In a mouse model of colitis (induced using dextran sulfate sodium), DBP glycoprotein was further demonstrated to attenuate colitis by reducing the disease activity index (via promotion of intestinal wound healing) and preventing histological alterations in the intestines. Similarly, a previous study demonstrated that SNP glycoprotein $(20 \mathrm{mg} / \mathrm{kg}$ ) prevented colitis in A/J mice by inhibiting $\mathrm{LDH}$ release, and nitric oxide and TBARS formation in serum, as well as downregulation of NF- $\mathrm{B}$, AP-1, iNOS and COX-2 gene expression in colonic tissues [56]. Taken together, these findings demonstrate that PGPs may be major active components mediating the traditional medicinal uses of $D$. batatas rhizomes and S. nigrum fruits, and support further exploration of the glycoproteins for the management and treatment of inflammatory bowel disease.

\subsection{Modulation of Glucose and Lipid Metabolism}

Abnormal glucose and lipid metabolism are critical features of metabolic syndrome. A few studies have demonstrated promising results on the role of PGPs on metabolic 
syndrome. For instance, GPG glycoprotein was reported to suppress changes in lipoprotein metabolism by preventing elevation in circulating low-density (LDL) and very low-density (VLDL) lipoproteins in Triton WR-1339 (400 mg/ $\mathrm{kg}$ ) and corn oil-induced dyslipidemia in mice. In a similar study, UDP glycoprotein suppressed triacylglycerol, total cholesterol and LDL levels with concomitant elevation in high density lipoprotein [50]. The potential effects of PGPs derived from Undaria pinnatifida on glucose metabolism using the inhibition of yeast and rat intestinal $\alpha$-glucosidases in vitro were investigated by Rafiquzzaman et al. [57]. The authors reported that the PGPs reversibly inhibited yeast and rat intestinal $\alpha$-glucosidase with $\mathrm{IC}_{50}$ values of 0.11 and $0.29 \mathrm{mg} / \mathrm{mL}$, respectively compared to the values 0.69 and $0.04 \mathrm{mg} / \mathrm{mL}$, respectively reported for acarbose, a known $\alpha$-glucosidase inhibitor. Theoretically, the large size of PGPs may impose steric hinderance, thus making them less plausible to bind the enzyme active site, when compared to small molecules typically used as enzyme inhibitors. Nonetheless, the authors further reported that the glycoprotein enhanced glucose uptake into yeast cell through unknown mechanisms [57]. The enhanced activity observed after intestinal phase digestion suggest that the peptides released from digestion of the PGPs may be better candidates for further studies in the prevention and management of metabolic syndrome.

\section{Perspective on Bioavailability and Safety of Phytoglycoproteins}

Despite the numerous bioactivities and health benefits attributed to glycoproteins and other drug-like phytochemicals, their effectual activities in humans greatly depend on their bioavailability and relative toxicity dose [58]. Bioavailability in humans refers to the effective amounts of bioactive substances that can successfully cross the intestinal epithelia barrier into the circulatory system and reach the designated cells where they elicit their physiological effects. Bioavailability of orally delivered molecules depends on the level of intestinal epithelia permeation, availability of specific transporters, and activation or inhibition of the efflux of permeability glycoproteins (P-glycoproteins) [59]. Although some biological activities of PGPs were observed in animal models, there are sparingly available studies on the bioavailability and toxicity profile of the PGPs. Generally, factors that could influence the bioavailability and toxicity of PGPs include the bulkiness and structural complexity, nature of glycosylation, constituent of polypeptide backbone, and susceptibility to hydrolytic/digestive enzymes in the gastrointestinal tract [60]. The bulkiness of PGPs depends on the nature and the number of the oligo-glycan moieties attached to the polypeptide chains by $\mathrm{N}$ - or O- linkages. Bulky and heavily glycosylated PGPs, which may reflect in their high molecular weight, would not easily permeate through intestinal mucus layer and epithelia [60]. More so, the potential therapeutic effects of PGPs depend on the type and position of glycosylation in the polypeptides. Studies from synthetic glycosylation of therapeutic peptides showed that N-glycosylated peptides are more readily bioavailable and show better therapeutic profiles than O-glycosylated peptides [61]. Notably, the susceptibility of PGPs to hydrolytic or digestive enzymes in the gastrointestinal could reduce their bioavailability and physiological bioactivities [62]. Stability of glycoproteins has been shown to be affected by the number and type of glycosylation irrespective of the glycoprotein source. This is because deglycosylation generally impacts negatively on the $\mathrm{pH}$, temperature and salt/alcohol stability of glycoproteins [63,64]. Unlike bioactive peptides whose biostability has been shown to depend on the chain length, net charge and physicochemical properties of the amino acid compositions [65-67], there is a dearth of information on the stability of dietary glycoproteins to enzymatic degradation during gastrointestinal transport and in circulation before reaching the target tissues. Considering that the majority of the biological activities of PGPs are reported in cell culture studies, further research should clarify the influence of the type and number of monosaccharides in oligosaccharide moieties in glycoproteins on the biostability, bioavailability and in vivo bioactivities. A study by Rafiquzzaman et al. [57] claimed that Undaria pinnatifida PGPs exhibited partial biostability to intestinal enzymatic hydrolysis in simulated experiment, but this was based on retention of bioactivity. To properly establish biostability, changes 
in the primary structure of PGPs need to be monitored at the different digestion phases. Prior to digestion and intestinal uptake, other components of the food matrix, such as micronutrients, may influence the transport, stability and bioactivities of peptides [68-73] and dietary polyphenols [74,75]. Based on this, further studies should investigate the effects of the vehicle or food matrix containing the PGPs on their biostability and bioaccessibility and consequently their bioavailability.

Table 1 shows the structural properties and bioactivities of several phytoglycoproteins. All the cell-based studies discussed in this review used PGPs in their intact forms to observe the health-promoting or beneficial effects. Practically, these results may not be easily reproduced in humans because of the biostability and bioaccessibility issues. Digestion of PGPs would also release several latent peptide motifs, which may evoke allergic reactions in some individuals due to the presence of potential epitopes. Furthermore, some of these peptides may activate the efflux of P-glycoproteins, thereby preventing the PGPs or their peptide fragments from crossing the intestinal epithelia [76]. There is a need for more studies to address the paucity of information on the relative bioavailability and toxicity profiles of plant N- or O-glycoproteins when administered orally. Studies directed towards enhancing bioavailability using delivery systems may also be beneficial for future development of PGPs as potent nutraceutical molecules.

Table 1. Sources, physicochemical properties and bioactive properties of isolated phytoglycoproteins.

\begin{tabular}{|c|c|c|c|c|c|c|}
\hline Name & MW & Source & PC (\%) & CC (\%) & Bioactivity & Reference \\
\hline UIB Glycoprotein & $29 \mathrm{kDa}$ & Urginea indica bulbs & 70 & 30 & Antifungal activity. & [3] \\
\hline DBD glycoprotein & $30 \mathrm{kDa}$ & Dioscorea batatas Decne & 16.25 & 83.75 & $\begin{array}{l}\text { Anti-inflammatory, anti-apoptosis, } \\
\text { antioxidant and intestinal } \\
\text { epithelial wound } \\
\text { healing properties. }\end{array}$ & {$[4,10,11]$} \\
\hline ZPDC Glycoprotein & $24 \mathrm{kDa}$ & Zanthoxylum piperitum DC fruit & 82 & 18 & Inhibits cell proliferation. & {$[5,47,55]$} \\
\hline GJE glycoprotein & $27 \mathrm{kDa}$ & Gardenia jasminoides Ellis & 42.35 & 57.65 & $\begin{array}{l}\text { Anticancer, hypolipidemic and } \\
\text { hepatoprotective properties. }\end{array}$ & {$[9,77]$} \\
\hline CO glycoprotein & $25.9 \mathrm{kDa}$ & Camellia oleifera Abel seeds & \multicolumn{2}{|c|}{ Not specified } & Anticancer activities & {$[30]$} \\
\hline SPG-56 Glycoprotein & $56 \mathrm{kDa}$ & Sweet potato variety Zhongshu-1 & 97.1 & 2.9 & $\begin{array}{c}\text { Anticancer activity against } \\
\text { breast cancer. }\end{array}$ & {$[31]$} \\
\hline SPG-8700 Glycoprotein & $8.7 \mathrm{kDa}$ & Sweet potato variety Zhongshu-1 & 73.4 & 26.6 & $\begin{array}{l}\text { Anticancer activity against } \\
\text { colon cancer. }\end{array}$ & [32] \\
\hline UDN glycoprotein & $116 \mathrm{kDa}$ & Ulmus davidiana Nakai & 21.35 & 78.65 & $\begin{array}{l}\text { Normalizes cell cycle arrest in } \\
\text { intestinal cancer cells and inhibits } \\
\text { inflammation and apoptosis in } \\
\text { normal cells. Anticancer, } \\
\text { anti-colitis, hypolipidemic and } \\
\text { antioxidant potentials. }\end{array}$ & {$[33,50,78-84]$} \\
\hline SNL Glycoprotein & $150 \mathrm{kDa}$ & Solanum nigrum Linne & 30.26 & 69.74 & $\begin{array}{l}\text { Anti-proliferative, anticancer, } \\
\text { apoptotic, antipyretic and } \\
\text { colitis-healing properties. }\end{array}$ & {$[34,47,56]$} \\
\hline SJSZ Glycoprotein & $38 \mathrm{kDa}$ & $\begin{array}{l}\text { Styrax japonica Siebold } \\
\text { and Zuccarini }\end{array}$ & 47.35 & 52.64 & $\begin{array}{l}\text { Anticancer, anti-proliferation, } \\
\text { anti-inflammatory, anti-colitis and } \\
\text { antioxidant properties. }\end{array}$ & {$[36-38,44,54,78,85-87]$} \\
\hline CTB glycoprotein & $75 \mathrm{kDa}$ & Cudrania tricuspidata Bureau & 27.5 & 72.5 & $\begin{array}{c}\text { Anti-inflammatory, } \\
\text { immunomodulatory, antioxidant } \\
\text { and anti-allergic properties. }\end{array}$ & {$[88,89]$} \\
\hline UDN glycoprotein & $120 \mathrm{kDa}$ & Ulmus davidiana Nakai & \multicolumn{2}{|c|}{ Not specified } & $\begin{array}{l}\text { Anticancer and } \\
\text { apoptotic properties. }\end{array}$ & {$[90,91]$} \\
\hline RVS glycoprotein & $36 \mathrm{kDa}$ & Rhus verniciflua Stokes fruit & 38.75 & 61.25 & Anti-apoptotic property. & {$[92,93]$} \\
\hline CDL glycoprotein & $48 \mathrm{kDa}$ & Codium decorticatum & 63.76 & 36.24 & Anticancer property. & {$[94]$} \\
\hline GSL glycoprotein & $18 \mathrm{kDa}$ & Geranium sibiricum linne & 89.55 & 10.45 & $\begin{array}{l}\text { Anti-oxidative and } \\
\text { anti-proliferative properties. }\end{array}$ & [95] \\
\hline CV Glycoprotein & $63,100 \mathrm{amu}$ & Chlorella vulgaris & 35.2 & 66.9 & Antitumor property. & [96] \\
\hline OFI glycoproteins & $90 \mathrm{kDa}$ & $\begin{array}{l}\text { Opuntia ficus-indica var. } \\
\text { saboten MAKINO }\end{array}$ & 62.46 & 37.54 & $\begin{array}{l}\text { Hypolipidemic, radical } \\
\text { scavenging and } \\
\text { antioxidant properties. }\end{array}$ & [97] \\
\hline GE Glycoprotein & $14 \mathrm{kDa}$ & Allium sativum bulb & \multirow{2}{*}{\multicolumn{2}{|c|}{$\begin{array}{l}\text { Not specified } \\
\text { Not specified }\end{array}$}} & Immunomodulatory property. & [98] \\
\hline GE Glycoprotein & $47 \mathrm{kDa}$ & Allium satioum bulb & & & Immunomodulatory property. & {$[99,100]$} \\
\hline HB Glycoprotein & $130 \mathrm{kDa}$ & haricot beans seeds & \multicolumn{2}{|c|}{ Not specified } & $\begin{array}{l}\text { Antiproliferative and } \\
\text { mitogenic properties. }\end{array}$ & [101] \\
\hline
\end{tabular}

MW, molecular weight; PC, protein content; CC, carbohydrate content.

\section{Conclusions and Future Prospects}

Glycoproteins sourced from different plants and mushrooms, mostly those grown in Asia, vary structurally based on molecular weight, carbohydrate/protein ratio and amino acid composition. These structural features contribute to variation in the biological activi- 
ties of PGPs. Interestingly, some PGPs have demonstrated multifunctional bioactivities, as shown by the 116-kDa PGPs from U. davidiana, 150-kDa PGPs from S. nigrum and 24-kDa PGPs from Z. piperitum fruit, most of which exhibited chemoprotective, anti-inflammatory, antioxidative activities, anticancer, hypolipidemic and hypoglycemic properties. This ability presents the PGPs as strong candidates for nutraceutical and functional food development for targeting diseases with multiple etiology. Despite the promising biological activities demonstrated in cell cultures and animals, there is a lack of studies on the physiological activities of PGPs in human subjects. Similarly, the contribution of gut microbiota in the reported biological activities of PGPs is unknown. This is particularly important given that the glycoproteins may not be entirely digestible in the upper gut due to the glycan residues. Therefore, future research is needed to examine the influence of undigested PGPs on the composition of gut microbiota and their activity in generating metabolites with biological activities. The biostability, intestinal transport mechanisms, and effects of vehicle/food matrix on bioaccessibility and bioavailability PGPs and their peptides need to be investigated. In addition, toxicity/immunogenicity profiles of the structurally intact and gastrointestinal digest of PGPs need to be investigated prior to clinical studies to establish their safety for human consumption. Lastly, it is important to elucidate the stereospecificity of PGPs and influence of such structural variations on their biological activities.

Author Contributions: Conceptualization, I.U.O. and C.C.U.; data curation, I.C.O., T.P.C.E. and I.U.O.; writing - original draft preparation, I.C.O., T.P.C.E. and I.U.O.; writing-review and editing, I.U.O. and C.C.U.; funding acquisition, I.U.O. and C.C.U. All authors have read and agreed to the published version of the manuscript.

Funding: This research was partially funded by the African German Network of Excellence in Sciences (AGNES), through the programme "AGNES Intra-Africa Mobility Grant for Junior Researchers" (I.U.O.), and the University Research Chairs Program of the University of Ottawa (C.C.U.).

Conflicts of Interest: The authors declare no conflict of interest.

\section{References}

1. Yeum, K.J.; Russell, R.M. Biological functions of plant pigment phytochemicals in humans. In Systems Biology of Free Radicals and Antioxidants; Laher, I., Ed.; Springer: Heidelberg/Berlin, Germany, 2015; pp. 4023-4045. [CrossRef]

2. Salavati, M.E.; Rezaeipour, V.; Abdullahpour, R.; Mousavi, N. Effects of graded inclusion of bioactive peptides derived from sesame meal on the growth performance, internal organs, gut microbiota and intestinal morphology of broiler chickens. Int. J. Pept. Res. Ther. 2020, 26, 1541-1548. [CrossRef]

3. Deepak, A.V.; Thippeswamy, G.; Shivakameshwari, M.N.; Salimath, B.P. Isolation and characterization of a 29-kDa glycoprotein with antifungal activity from bulbs of Urginea indica. Biochem. Biophys. Res. Comm. 2003, 311, 735-742. [CrossRef]

4. Oh, P.S.; Lim, K.T. Glycoprotein isolated from Dioscorea batatas Decne modulates expressions of IL-4 and IL-10 in primarycultured mouse lymphocytes. Cell Biochem. Funct. 2009, 27, 316-322. [CrossRef] [PubMed]

5. Lee, J.; Lee, S.J.; Lim, K.T. Preventive effects of ZPDC glycoprotein (24 kDa) on hepatotoxicity induced by mercury chloride in vitro and in vivo. Cell Biochem. Funct. 2014, 32, 520-529. [CrossRef] [PubMed]

6. Shruthi, R.R.; Venkatesh, Y.P.; Muralikrishna, G. Structural and functional characterization of a novel immunomodulatory glycoprotein isolated from ajowan (Trachyspermum ammi L.). Glycoconj. J. 2017, 34, 499-514. [CrossRef] [PubMed]

7. Kim, J.Y.; Lee, Y.M.; Park, J.P.; Lim, K.T.; Lee, S.J. Phytoglycoprotein isolated from Dioscorea batatas Decne promotes intestinal epithelial wound healing. Chin. J. Nat. Med. 2020, 18, 738-748. [CrossRef] [PubMed]

8. Park, J.B.; Kim, D.W.; Lim, K.T.; Oh, S.; Lee, S.J. A 75 kDa glycoprotein isolated from Cudrania tricuspidata Bureau induces colonic epithelial proliferation and ameliorates mouse colitis induced by dextran sulfate sodium. Chin. J. Nat. Med. 2021, 19, 46-55. [CrossRef]

9. Lee, S.J.; Oh, P.S.; Lim, K.T. Hepatoprotective and hypolipidaemic effects of glycoprotein isolated from Gardenia jasminoides Ellis in mice. Clin. Exp. Pharmacol. Physiol. 2006, 33, 925-933. [CrossRef]

10. Oh, P.S.; Lim, K.T. Blocking of intracellular ROS production by phytoglycoprotein (30 kDa) causes anti-proliferation in bisphenol A-stimulated Chang liver cells. J. Appl. Toxicol. 2008, 28, 749-758. [CrossRef]

11. Oh, P.; Lim, K. Protective activity of $30 \mathrm{kDa}$ phytoglycoprotein from glucose/glucose oxidase-induced cell death in primary cultured mouse thymocytes. Environ. Toxicol. Pharmacol. 2008, 25, 114-120. [CrossRef]

12. Reily, C.; Stewart, T.J.; Renfrow, M.B.; Novak, J. Glycosylation in health and disease. Nat. Rev. Nephrol. 2019, 15, 346-366. [CrossRef] 
13. Forrest, S.; Welch, M. Arming the troops: Post-translational modification of extracellular bacterial proteins. Sci. Prog. 2020, 103, 003685042096431. [CrossRef]

14. Strasser, R. Plant protein glycosylation. Glycobiology 2016, 26, 926-939. [CrossRef] [PubMed]

15. Nguema-Ona, E.; Vicré-Gibouin, M.; Gotté, M.; Plancot, B.; Lerouge, P.; Bardor, M.; Driouich, A. Cell wall O-glycoproteins and N-glycoproteins: Aspects of biosynthesis and function. Front. Plant Sci. 2014, 5, 499. [CrossRef] [PubMed]

16. Temple, H.; Saez-Aguayo, S.; Reyes, F.C.; Orellana, A. The inside and outside: Topological issues in plant cell wall biosynthesis and the roles of nucleotide sugar transporters. Glycobiology 2016, 26, 913-925. [CrossRef]

17. Strasser, R. Biological significance of complex N-glycans in plants and their impact on plant physiology. Front. Plant Sci. 2014, 5, 363. [CrossRef]

18. Ruiz-May, E.; Kim, S.J.; Brandizzi, F.; Rose, J.K.C. The secreted plant N-glycoproteome and associated secretory pathways. Front. Plant Sci. 2012, 3, 117. [CrossRef]

19. Breitling, J.; Aebi, M. N-linked protein glycosylation in the endoplasmic reticulum. Cold Spring Harbor Perspect. Biol. 2013, 5. [CrossRef] [PubMed]

20. Gorres, K.L.; Raines, R.T. Prolyl 4-hydroxylase. Crit. Rev. Biochem. Mol. Biol. 2010, 45, 106-124. [CrossRef] [PubMed]

21. Goettig, P. Effects of glycosylation on the enzymatic activity and mechanisms of proteases. Int. J. Mol. Sci. 2016, 17, 1969. [CrossRef]

22. Mariño, K.; Bones, J.; Kattla, J.J.; Rudd, P.M. A systematic approach to protein glycosylation analysis: A path through the maze. Nat. Chem. Biol. 2010, 6, 713-723. [CrossRef]

23. Lee, S.J.; Lim, K.T. ZPDC glycoprotein inhibits inflammation-related cytokine and protein via nuclear factor-kappa B in dextran sulfate sodium-stimulated ICR mouse. Biomed. Pharmacother. 2009, 63, 528-536. [CrossRef]

24. Lee, J.; Lim, K. Inhibitory effect of plant-originated glycoprotein $(27 \mathrm{kDa})$ on expression of matrix metalloproteinase-9 in cadmium chloride-induced BNLCL.2 cells. J. Trace Elem. Med. Biol. 2011, 25, 239-246. [CrossRef]

25. Heo, K.S.; Lim, K.T. Antioxidative effects of glycoprotein isolated from Solanum nigrum L. J. Med. Food 2004, 7, 349-357. [CrossRef]

26. Thangam, R.; Senthilkumar, D.; Suresh, V.; Sathuvan, M.; Sivasubramanian, S.; Pazhanichamy, K.; Gorlagunta, P.K.; Kanna, S.; Gunasekaran, P.; Rengasamy, R.; et al. Induction of ROS-dependent mitochondria-mediated intrinsic apoptosis in MDA-MB-231 cells by glycoprotein from Codium decorticatum. J. Agric. Food Chem. 2014, 62, 3410-3421. [CrossRef]

27. Wang, M.; Ma, H.; Tian, C.; Liu, S.; Ye, X.; Zhou, D.; Li, Y.; Hui, N.; Li, X. Bioassay-guided isolation of glycoprotein SPG-56 from sweet potato Zhongshu-1 and its anti-colon cancer activity in vitro and in vivo. J. Funct. Foods 2017, 35, 315-324. [CrossRef]

28. Roth, Z.; Yehezkel, G.; Khalaila, I. Identification and quantification of protein glycosylation. Int. J. Carbohyd. Chem. 2012, 1-10. [CrossRef]

29. Lojkova, L.; Vranová, V.; Formánek, P.; Drápelová, I.; Brtnicky, M.; Datta, R. Enantiomers of carbohydrates and their role in ecosystem interactions: A review. Symmetry 2020, 12, 470. [CrossRef]

30. Li, T.; Meng, X.; Wu, C.; Fan, G.; Yang, J.; Pan, W. Anticancer activity of a novel glycoprotein from Camellia oleifera Abel seeds against hepatic carcinoma in vitro and in vivo. Int. J. Biol. Macromol. 2019, 136, 284-295. [CrossRef]

31. Li, Z.; Yu, Y.; Wang, M.; Han, B.; Jiang, P.; Ma, H.; Li, Y.; Tian, C.; Zhou, D.; Li, X.; et al. Anti-breast cancer activity of SPG-56 from sweet potato in MCF-7 bearing mice in situ through promoting apoptosis and inhibiting metastasis. Sci. Rep. 2019, 9, 146. [CrossRef]

32. Tian, C.; Wang, M.; Liu, S.; Ma, H.; He, K.; Zhou, D. A new glycoprotein SPG-8700 isolated from sweet potato with potential anti-cancer activity against colon cancer. Nat. Prod. Res. 2018, 6419, 1-7. [CrossRef] [PubMed]

33. Lee, S.; Lim, K. A 116-kDa phytoglycoprotein inhibits aberrant crypt foci formation through modulation of manganese superoxide dismutase, inducible nitric oxide synthase, cyclooxygenase-2, nuclear factor-kappa B, activator protein-1, and proliferating cell nuclear an. 1. Eur. J. Cancer Prev. 2008, 17, 479-488. [CrossRef] [PubMed]

34. Oh, P.S.; Lim, K.T. HeLa cells treated with phytoglycoprotein (150 kDa) were killed by activation of caspase 3 via inhibitory activities of NF-kB and AP-1. J. Biomed. Sci. 2007, 14, 223-232. [CrossRef] [PubMed]

35. Quintero-Fabián, S.; Arreola, R.; Becerril-Villanueva, E.; Torres-Romero, J.C.; Arana-Argáez, V.; Lara-Riegos, J.; RamírezCamacho, M.A.; Alvarez-Sánchez, M.E. Role of matrix metalloproteinases in angiogenesis and cancer. Front. Oncol. 2019, 9, 1370. [CrossRef]

36. Lee, S.J.; Lim, K.T. Inductive effect of phytoglycoprotein ( $38 \mathrm{kDa})$ on G0/G1 arrest and apoptosis in diethylnitrosamine-treated ICR mice. Mol. Cell Biochem. 2013, 375, 31-38. [CrossRef]

37. Lee, S.J.; Lim, K.T. Growth of HepG2 cells was suppressed through modulation of STAT6/IL-4 and IL-10 in RAW 264.7 cells treated by phytoglycoprotein (38 kDa). Inflammation 2013, 36, 549-560. [CrossRef]

38. Lee, J.; Lim, K.T. Preventive effect of phytoglycoprotein $(38 \mathrm{kDa})$ on expression of alpha-fetoprotein and matrix metalloproteinase9 in diethylnitrosamine-treated ICR mice. Drug Chem. Toxicol. 2012, 35, 277-284. [CrossRef]

39. Oh, P.S.; Lee, S.J.; Lim, K.T. Glycoprotein isolated from Rhus verniciflua STOKES inhibits inflammation-related protein and nitric oxide production in LPS-stimulated RAW 264.7 cells. Biol. Pharm. Bull. 2007, 30, 111-116. [CrossRef]

40. Lee, J.; Lim, K.T. Inhibitory effect of phytoglycoprotein $(24 \mathrm{kDa})$ on allergy-related factors in compound $48 / 80$-induced mast cells in vivo and in vitro. Int. Immunopharmacol. 2010, 10, 591-599. [CrossRef]

41. Lee, J.; Lim, K.T. Expression of TNF- $\alpha$ and IL-6 in HMC-1 cells treated with bisphenol A is attenuated by plant-originating glycoprotein (75 kDa) by blocking p38 MAPK. Naunyn-Schmied. Arch. Pharmacol. 2010, 382, 51-61. [CrossRef] 
42. Shim, J.U.; Lim, K.T. Inhibitory effect of glycoprotein isolated from Cudrania tricuspidata Bureau on expression of inflammationrelated cytokine in bisphenol A-treated HMC-1 cells. Inflammation 2009, 32, 211-217. [CrossRef]

43. Lee, S.J.; Lim, K.T. Inhibitory effect of ZPDC glycoprotein on the expression of inflammation-related cytokines through p38 MAP kinase and JNK in lipopolysaccharide-stimulated RAW 264.7 cells. Inflamm. Res. 2009, 58, 184-191. [CrossRef]

44. Lee, J.; Lim, K.T. SJSZ glycoprotein (38 kDa) modulates expression of IL-2, IL-12, and IFN- $\gamma$ in cyclophosphamide-induced Balb/c. Inflamm. Res. 2012, 61, 1319-1328. [CrossRef]

45. Park, H.Y.; Yu, A.R.; Choi, I.W.; Hong, H.D.; Lee, K.W.; Choi, H.D. Immunostimulatory effects and characterization of a glycoprotein fraction from rice bran. Int. Immunopharmacol. 2013, 17, 191-197. [CrossRef]

46. Park, H.Y.; Yu, A.R.; Hong, H.D.; Kim, H.; Lee, K.W.; Choi, H.D. Immunomodulatory effects of nontoxic glycoprotein fraction isolated from rice bran. Planta Med. 2016, 82, 606-611. [CrossRef]

47. Lee, S.J.; Oh, P.S.; Ko, J.H.; Lim, K.; Lim, K.T. A 150-kDa glycoprotein isolated from Solanum nigrum L. has cytotoxic and apoptotic effects by inhibiting the effects of protein kinase $\mathrm{C}$ alpha, nuclear factor-kappa B and inducible nitric oxide in HCT-116 cells. Cancer Chemother. Pharmacol. 2004, 54, 562-572. [CrossRef]

48. Lee, S.J.; Oh, P.S.; Ko, J.H.; Lim, K.T.; Lim, K. Protective effect of glycoprotein isolated from Ulmus davidiana Nakai on carbon tetrachloride-induced mouse liver injury. J. Pharm. Pharmacol. 2006, 58, 143-152. [CrossRef]

49. Ko, J.H.; Lim, K.T. Glycoprotein isolated from Ulmus davidiana NAKAI protects against carbon tetrachloride-induced liver injury in the mouse. J. Pharmacol. Sci. 2006, 101, 205-213. [CrossRef]

50. Ko, J.H.; Lee, S.J.; Lim, K.T. Hypolipidemic effect and antioxidant activity of glycoprotein isolated from Ulmus davidiana Nakai in Triton WR-1339-treated mouse. Cell Biochem. Funct. 2007, 25, 495-500. [CrossRef]

51. Heo, K.S.; Lee, S.J.; Ko, J.H.; Lim, K.; Lim, K.T. Glycoprotein isolated from Solanum nigrum L. inhibits the DNA-binding activities of NF- $\mathrm{KB}$ and AP-1, and increases the production of nitric oxide in TPA-stimulated MCF-7 cells. Toxicol. In Vitro 2004, 18, 755-763. [CrossRef]

52. Lee, S.J.; Lim, K.T. Chemopreventive effect of plant-originated glycoprotein on colitis-mediated colorectal cancer in A/J mice. J. Biomed. Sci. 2008, 15, 111-121. [CrossRef]

53. Lee, J.; Lee, S.; Lim, K. ZPDC glycoprotein ( $24 \mathrm{kDa})$ induces apoptosis and enhances activity of NK cells in N -nitrosodiethylamineinjected Balb/c. Cell Immunol. 2014, 289, 1-6. [CrossRef] [PubMed]

54. Lim, K.T. Glycoprotein isolated from Solanum nigrum L. kills HT-29 cells through apoptosis. J. Med. Food 2005, 8, 215-226. [CrossRef] [PubMed]

55. Li, W.; Deng, X.; Chen, T. Exploring the modulatory effects of gut microbiota in anti-cancer therapy. Front. Oncol. 2021, 11, 644454 [CrossRef]

56. Lee, S.J.; Lim, K.T. Inhibitory effect of SJSZ glycoprotein (38 kDa) on expression of heat shock protein 27 and 70 in chromium (VI)-treated hepatocytes. Mol. Cell Biochem. 2012, 359, 45-57. [CrossRef] [PubMed]

57. Joo, H.Y.; Lim, K.; Lim, K.T. Phytoglycoprotein (150 kDa) isolated from Solanum nigrum Linne has a preventive effect on dextran sodium sulfate-induced colitis in A/J mouse. J. Appl. Toxicol. 2009, 29, 207-213. [CrossRef] [PubMed]

58. Rafiquzzaman, S.M.; Lee, J.M.; Ahmed, R.; Lee, J.H.; Kim, J.M.; Kong, I.S. Characterisation of the hypoglycaemic activity of glycoprotein purified from the edible brown seaweed, Undaria pinnatifida. Int. J. Food Sci. Technol. 2015, 50, 143-150. [CrossRef]

59. Kim, T.H.; Shin, S.; Yoo, S.D.; Shin, B.S. Effects of phytochemical P-glycoprotein modulators on the pharmacokinetics and tissue distribution of doxorubicin in mice. Molecules 2018, 23, 349. [CrossRef]

60. Pathak, K.; Raghuvanshi, S. Oral bioavailability: Issues and solutions via nanoformulations. Clin. Pharmacokinet. 2015, 54, 325-357. [CrossRef]

61. Rein, M.J.; Renouf, M.; Cruz-Hernandez, C.; Actis-Goretta, L.; Thakkar, S.K.; da Silva Pinto, M. Bioavailability of bioactive food compounds: A challenging journey to bioefficacy. Br. J. Clin. Pharmacol. 2013, 75, 588-602. [CrossRef]

62. Moradi, S.V.; Hussein, W.M.; Varamini, P.; Simerska, P.; Toth, I. Glycosylation, an effective synthetic strategy to improve the bioavailability of therapeutic peptides. Chem. Sci. 2016, 7, 2492-2500. [CrossRef]

63. Wang, C.; Eufemi, M.; Turano, C.; Giartosio, A. Influence of the carbohydrate moiety on the stability of glycoproteins. Biochemistry 1996, 35, 7299-7307. [CrossRef]

64. Khan, R.H.; Rasheedi, S.; Haq, S.K. Effect of pH, temperature and alcohols on the stability of glycosylated and deglycosylated stem bromelain. J. Biosci. 2003, 28, 709-714. [CrossRef]

65. Solá, R.J.; Griebenow, K. Effects of glycosylation on the stability of protein pharmaceuticals. J. Pharm. Sci. 2009, 98, 1223-1245. [CrossRef]

66. Karaś, M. Influence of physiological and chemical factors on the absorption of bioactive peptides. Int. J. Food Sci. Technol. 2019, 54, 1486-1496. [CrossRef]

67. Amigo, L.; Hernández-Ledesma, B. Current evidence on the bioavailability of food bioactive peptides. Molecules 2020, 25, 4479. [CrossRef]

68. Udenigwe, C.C.; Abioye, R.O.; Okagu, I.U.; Obeme-Nmom, J.I. Bioaccessibility of bioactive peptides: Recent advances and perspectives. Curr. Opin. Food Sci. 2021, 37, 182-189. [CrossRef]

69. O'Loughlin, I.B.; Kelly, P.M.; Murray, B.A.; FitzGerald, R.J.; Brodkorb, A. Molecular characterization of whey protein hydrolysate fractions with ferrous chelating and enhanced iron solubility capabilities. J. Agric. Food Chem. 2015, 63, 2708-2714. [CrossRef] 
70. Udenigwe, C.C.; Fogliano, V. Food matrix interaction and bioavailability of bioactive peptides: Two faces of the same coin? J. Funct. Foods 2017, 35, 9-12. [CrossRef]

71. Caetano-Silva, M.E.; Mariutti, L.R.B.; Bragagnolo, N.; Bertoldo-Pacheco, M.T.; Netto, F.M. Whey peptide-iron complexes increase the oxidative stability of oil-in-water emulsions in comparison to iron salts. J. Agric. Food Chem. 2018, 66, 1981-1989. [CrossRef]

72. Zhang, K.; Li, B.; Chen, Q.; Zhang, Z.; Zhao, X.; Hou, H. Functional calcium binding peptides from pacific cod (Gadus macrocephalus) bone: Calcium bioavailability enhancing activity and antiosteoporosis effects in the ovariectomy-induced osteoporosis rat model. Nutrients 2018, 10, 1325. [CrossRef]

73. Sun, X.; Acquah, C.; Aluko, R.E.; Udenigwe, C.C. Considering food matrix and gastrointestinal effects in enhancing bioactive peptide absorption and bioavailability. J. Funct. Foods 2020, 64, 103680. [CrossRef]

74. Silberberg, M.; Morand, C.; Manach, C.; Scalbert, A.; Remesy, C. Co-administration of quercetin and catechin in rats alters their absorption but not their metabolism. Life Sci. 2005, 77, 3156-3167. [CrossRef]

75. Scholz, S.; Williamson, G. Interactions affecting the bioavailability of dietary polyphenols in vivo. Int. J. Vitam. Nutr. Res. 2007, 77, 224-235. [CrossRef]

76. Dewanjee, S.; Dua, T.K.; Bhattacharjee, N.; Das, A.; Gangopadhyay, M.; Khanra, R.; Zia-Ul-Haq, M. Natural products as alternative choices for P-glycoprotein (P-gp) inhibition. Molecules 2017, 22, 871. [CrossRef]

77. Lee, J.; Lim, K.T. Preventive effect of phytoglycoprotein $(27 \mathrm{kDa})$ on inflammatory factors at liver injury in cadmium chlorideexposed ICR mice. J. Cell. Biochem. 2011, 112, 694-703. [CrossRef]

78. Lee, S.J.; Lim, K.T. Activity of tumor necrosis factor-a blocked by phytoglycoprotein (38 kDa) at initiation stage in Nnitrosodiethylamine-induced ICR mice. Mol. Cell Biochem. 2012, 362, 177-186. [CrossRef]

79. Ko, J.; Lee, S.; Lim, K. 116 kDa glycoprotein isolated from Ulmus davidiana Nakai (UDN) inhibits glucose/glucose oxidase (G/GO)-induced apoptosis in BNLCL.2 cells. J. Ethnopharmacol. 2005, 100, 339-346. [CrossRef]

80. Lee, S.J.; Lim, K.T. Inhibitory effect of phytoglycoprotein on tumor necrosis factor- $\alpha$ and interleukin- 6 at initiation stage of colon cancer in 1,2-dimethylhydrazine-treated ICR mice. Toxicol. Appl. Pharmacol. 2007, 225, 198-205. [CrossRef]

81. Lee, S.J.; Lim, K.T. Glycoprotein isolated from Ulmus davidiana Nakai regulates expression of iNOS and COX-2 in vivo and in vitro. Food Chem. Toxicol. 2007, 45, 990-1000. [CrossRef]

82. Lee, S.J.; Lim, K.T. UDN glycoprotein inhibits activator protein-1 and matrix metalloproteinase-9 via blocking of oxygen radicals in HT-29 cells. Mol. Cell Biochem. 2007, 304, 13-23. [CrossRef]

83. Lee, S.J.; Lim, K.T. Glycoprotein isolated from Ulmus davidiana Nakai modulates inflammatory related factors in mouse colonic tissues. Environ. Toxicol. Pharmacol. 2007, 23, 234-241. [CrossRef] [PubMed]

84. Lee, S.J.; Lim, K.T. UDN glycoprotein regulates activities of manganese-superoxide dismutase, activator protein-1, and nuclear factor-kB stimulated by reactive oxygen radicals in lipopolysaccharide-stimulated HCT-116 cells. Cancer Lett. 2007, 254, 274-287. [CrossRef] [PubMed]

85. Lee, J.; Lim, K. Inhibitory effect of phytoglycoprotein (38 kDa) on expression of matrix metalloproteinase-9 in 12-Otetradecanoylphorbol-13-acetate-treated HepG2cells. Naunyn-Schmied. Arch. Pharmacol. 2011, 9, 185-196. [CrossRef] [PubMed]

86. Lee, S.J.; Lee, J.; Song, S.; Lim, K.T. Glycoprotein isolated from Styrax japonica Siebold et al. Zuccarini inhibits oxidative and pro-inflammatory responses in HCT116 colonic epithelial cells and dextran sulfate sodium-treated ICR mice. Food Chem. Toxicol. 2016, 87, 12-22. [CrossRef] [PubMed]

87. Lee, J.; Lim, K.T. Modulatory effect of phytoglycoprotein (38 kDa) on cyclin D1/CDK4 in BNL CL.2 cells induced by N-methylN'-nitro-N-nitrosoguanidine. Naunyn-Schmied. Arch. Pharmacol. 2012, 385, 181-190. [CrossRef]

88. Oh, P.; Lim, K. Phytoglycoprotein $(75 \mathrm{kDa})$ isolated from Cudrania tricuspidata Bureau inhibits expression of interleukin-4 in the presence of di(2-ethylhexyl)phthalate via modulation of p38 mitogen-activated protein kinase in primary-cultured mouse thymocytes. J. Appl. Toxicol. 2009, 29, 496-504. [CrossRef]

89. Park, C.; Lim, K. Phytoglycoprotein $(75 \mathrm{kDa})$ suppresses release of histamine and expression of IL-4 and IFN- $\gamma$ in BPA-treated RBL-2H3 Cells. Immun. Investig. 2010, 39, 171-185. [CrossRef]

90. Son, Y.K.; Lee, K.Y.; Cho, K.C.; Chung, Y.; Kim, J.G.; Jeon, Y.M.; Jang, Y.S.; Lee, J.C. Inhibitory effects of glycoprotein-120 (G-120) from Ulmus davidiana Nakai on cell growth and activation of matrix metalloproteinases. Mol. Cells 2004, 18, 163-170.

91. Lee, S.J.; Heo, K.S.; Oh, P.S.; Lim, K.; Li, K.T. Glycoprotein isolated from Ulmus davidiana Nakai inhibits TPA-induced apoptosis through nuclear factor-kappa B in NIH/3T3 cells. Toxicol. Lett. 2004, 146, 159-174. [CrossRef]

92. Hye, J.; Yeon, H.; Hoon, D.; Kim, H. Inhibition of the PI3K-Akt/PKB survival pathway enhanced an ethanol extract of Rhus verniciflua Stokes-induced apoptosis via a mitochondrial pathway in AGS gastric cancer cell lines. Cancer Lett. 2005, 265, 197-205. [CrossRef]

93. Ko, J.; Lee, S.; Lim, K. 36 kDa Glycoprotein isolated from Rhus verniciflua Stokes fruit has a protective activity to glucose / glucose oxidase-induced apoptosis in NIH/3T3 cells. Toxicol. In Vitro 2005, 19, 353-363. [CrossRef]

94. Senthilkumar, D.; Jayanthi, S. Partial characterization and anticancer activities of purified glycoprotein extracted from green seaweed Codium decorticatum. J. Funct. Foods 2016, 25, 323-332. [CrossRef]

95. Shim, J.; Lim, K. Anti-oxidative and anti-proliferative character of glycoprotein isolated from geranium sibiricum linne in Chang liver cells. Environ. Toxicol. Pharmacol. 2008, 26, 320-324. [CrossRef] 
96. Noda, K.; Ohno, N.; Tanaka, K.; Kamiya, N.; Okuda, M.; Yadomae, T. A water-soluble antitumor glycoprotein from Chlorella vulgaris. Planta Med. 1996, 62, 423-426. [CrossRef]

97. Oh, P.S.; Lim, K.T. Glycoprotein $(90 \mathrm{kDa})$ isolated from Opuntia ficus-indica var. saboten MAKINO lowers plasma lipid level through scavenging of intracellular radicals in Triton WR-1339-induced mice. Biol. Pharm. Bull. 2006, 29, 1391-1396. [CrossRef]

98. Ghazanfari, T.; Hassan, Z.M.; Ebrahimi, M. Immunomodulatory activity of a protein isolated from garlic extract on delayed type hypersensitivity. Int. Immunopharmacol. 2002, 2, 1541-1549. [CrossRef]

99. Daneshmandi, S.; Hajimoradi, M.; Ahmadabad, H.N.; Hassan, Z.M.; Roudbary, M.; Ghazanfari, T. Effect of 14-kDa and 47-kDa protein molecules of age garlic extract on peritoneal macrophages. Immunopharmacol. Immunotoxicol. 2011, 33, 21-27. [CrossRef]

100. Ahmadabad, H.N.; Zuhair, M.H.; Safari, E.; Bozorgmehr, M.; Moazzeni, S. Evaluation of the effect of the $47 \mathrm{kDa}$ protein isolated from aged garlic extract on dendritic cells. Iran. J. Basic Med. Sci. 2012, 15, 745-751.

101. Wong, J.H.; Ng, T.B. A homotetrameric agglutinin with antiproliferative and mitogenic activities from haricot beans. J. Chromatogr. B 2005, 828, 130-135. [CrossRef] 